\title{
Petroleum Industry of France
}

\begin{abstract}
$\mathrm{M}^{\mathrm{s}}$
R. VICTOR FORBIN'S recent article on the French petroleum industry ( $L a$ Nature, No. 2952, 385-396, May $I, 1935$ ) is in effect an unanswerable vindication of France's claim to recognition as a petroleum power in the world to-day. Admittedly, at the beginning of this century and during the great development of the world petroleum industry, actuated by invention and universal adoption of the internal combustion engine, France had little right to recognition, for at this time tariff protection had been withdrawn and she was only able to supply 10 per cent of her domestic requirements of petroleum and products. This position was more or less maintained until 1925, when l'Office National des Combustibles Liquides was founded to give expression to the French desire "de devenir une puissance pétrolière". Close co-operation between this body and the Government led to drastic reorganisation of the entire industry and finally, in 1928 , to the passing of a law which is now regarded as the charter of the French petroleum industry.

Under the new regime initiated by this law, authorisations were granted for importation and refining of crude petroleum in France for periods up to twenty years. Eleven industrial concerns contributed capital amounting to nearly 3,000 million francs for the erection of refineries at suitable places along the coast. Thus France acquired at Le Havre, at the mouths of the Rivers Loire, Gironde and Rhône, etc., some of, perhaps, the most modern refineries in the world. Systematic co-operation
\end{abstract}

within the industry and far-seeing dispensation of resources led to the optimum equipment of each refinery for some particular type of raw material. Some are capable of producing the whole range of petroleum products, while others confine their activities to production of petrol, kerosene, gas-oil, etc.; throughout the industry there is a wholehearted spirit of co-operation and a common desire that France should have a petroleum industry comparable with that of other nations.

France is now definitely reaping the benefit of this far-sighted policy initiated some five years ago, for when the first consignment of Iraq oil was conveyed by the pipe line to Tripoli in August 1934, there were new tank-ships ready for its conveyance to Le Havre and everything was in readiness for its reception. During the last five months of 1934, after completion of both branches of the Iraq pipe line, 600,000 tons of erude oil were exported from the twin ports of Tripoli and Haifa, 520,000 tons of which were destined for France. In 1934 French refineries treated $3 \frac{1}{4}$ million tons of raw material, and it is estimated that this quantity will be increased to 4 million tons in 1935 , as compared with $1,034,819$ tons in 1932 and $2,739,305$ tons in 1933 .

During the first eight months of 1934, France exported 28,647 tons of kerosene and 682,292 tons of gasoline to Great Britain, Switzerland, Italy and other countries. These facts and figures should confute those who are still under the impression that the French petroleum industry is directed by foreigners.

\section{Pollination Mechanism in Conifers}

\section{$\mathrm{P}$} ROF. JOSEPH DOYLE and Miss Mary O'Leary have published (Sci. Proc. Roy. Dublin Soc., 21 , N.S., Nos. 19, 20 and 21, February 1935) a series of papers upon the pollination mechanisms in conifers. Their researches include records of intensive observations in the field, which are interpreted most interestingly in the light of the wide knowledge of the senior author of the comparative morphology of the reproductive structures in the group.

The authors point out that our knowledge of the movement of pollen on to the nucellus in Pinus has so far rested upon second-hand statements, most of them derived from some incidental observations by Strasburger. Strasburger appears to have assumed, on the basis of other well-known cases, that a fertilisation drop was formed and, in view of their turgid transparent appearance, to have ascribed its formation to the two characteristic prolongations of the integument beyond the micropyle.

As the result of very patient investigation, the Irish observers have at last seen this fertilisation drop-but at 2 a.m. in the morning-and by 7.30 a.m. every ovule is dry! This secretion appears to come from the nucellus, and though at night it may be found in almost every mature unfertilised ovule as it wells out of the micropyle and part of the way along the micropylar projection, it usually soon picks up some pollen grains from these arms. When these are immersed in the fluid, in the inverted ovule, they rapidly float with their winged surface uppermost on to the nucellus; the grain is thus brought against the nucellus with the surface towards it through which the pollen tube emerges. More remarkable still, within ten minutes of the grain being thus transferred to the nucellus, the drop is once more reabsorbed while it still remains in the unpollinated ovule. The authors have tested this by introducing pollen into the drop at night. They argue cogently that the function thus suggested for the winged expansions to the pollen grain is much more reasonable than its use for transport of the grains in the air, as the larger grains of Larix and Pseudotsuga are without wings.

On the other hand, the authors have to solve the problem how these wingless pollen grains of Larix also reach the surface of an inverted ovule. In Saxegothoea and Cedrus they describe the germination of pollen grains well away from the micropyle and their growth to the nucellus : they also figure and discuss the function of the stigma-like projections in the integuments of Pseudotsuga and Larix. These papers are full of stimulating discussion of new data that are a permanent contribution to our knowledge of the pollination mechanisms of the conifer. 